\title{
BLOOD VISCOSITY AS A DETERMINING FACTOR OF ISCHEMIC STROKE OUTCOMES EVALUATED WITH NIHSS AND MRS ON DAY 7 AND 30 POST-THROMBOLYSIS
}

\author{
AL RASYID ${ }^{*}$, SALIM HARRIS ${ }^{1}$, MOHAMMAD KURNIAWAN ${ }^{1}$, TAUFIK MESIANOํㅜ, RAKHMAD HIDAYAT ${ }^{1}$, GOGOR \\ MEISADONA ${ }^{1}$
}

1Department of Neurology, Faculty of Medicine, University of Indonesia/Cipto Mangunkusumo Hospital, Jakarta 10430, Indonesia

Email: alrasyid50@yahoo.com

Received: 08 Jul 2019, Revised and Accepted: 10 Aug 2019

ABSTRACT

Objective: This study aimed to analyze blood viscosity as a determining factor of ischemic stroke outcomes evaluated with National Institutes of Health Stroke Scale (NIHSS) and modified Rankin Scale (mRS) on day 7 and 30 post-thrombolysis.

Methods: This study was a 4-months cohort study taking place in Cipto Mangunkusumo General Hospital from January to April 2017. Subjects were collected at the Emergency Department or Neurology Outpatient Department. Eligible patients gave informed consent. Patients underwent numerous examinations, including blood viscosity test using digital microcapillary (DM) instrument. Outcomes of patients were identified on day 7 and day 30 post-thrombolysis using NIHSS and mRS, respectively.

Results: Most acute ischemic stroke patients (88.6\%) had blood hyperviscosity. 9.1\% patients had poorer neurologic deficit on day 7 evaluated with NIHSS and $18.2 \%$ patients had poor outcome on day 30 evaluated with mRS. All patients with normal blood viscosity did not have a poorer neurologic deficit on day-7-evaluation.

Conclusion: Blood viscosity determines the outcomes of acute ischemic stroke patients on day 7 and day 30 post-thrombolysis.

Keywords: Blood viscosity, Thrombolysis, Ischemic stroke, Indonesia

(c) 2019 The Authors. Published by Innovare Academic Sciences Pvt Ltd. This is an open access article under the CC BY license (http://creativecommons.org/licenses/by/4.0/) DOI: http://dx.doi.org/10.22159/ijpps.2019v11i9.34820

\section{INTRODUCTION}

Stroke is the second leading cause of death and the third leading cause of disability [1-5]. Stroke hold accountable for 5 million deaths and 5 million permanent disabilities in the world [6]. Ischemic stroke has the highest prevalence of all types of stroke (87\%) [7] Stroke causes the highest mortality from the non-communicable disease group in Indonesia with ischemia as the main etiology [8]. In Indonesia, stroke prevalence is $10.9 / 1000$ population (2018) [9]

Blood viscosity is the blood flow resistance due to friction caused by the difference in the speed of blood flow movement through the lamina [10]. Blood viscosity is one of the components determining the flow of the blood. Many studies have shown a correlation between the blood flow and hemostasis as well as thrombosis. Blood viscosity is associated with the prothrombic condition $[11,12]$. The blood viscosity value varies between individuals and may play an important role in ischemic stroke and transient ischemic disease (TIA) as its value is increased in some of those patients, $48 \%$ and $34 \%$, respectively [13]. Blood viscosity -as part of the blood flow, is associated with the pathophysiology of cerebral ischemia. Blood hyperviscosity is found in most patients with acute ischemic stroke [14]. Szapary et al. study found there was an increase of blood viscosity in ischemic stroke patients and Meliala et al. study stated that blood hyperviscosity contributed as one of the stroke risk factors $[15,16]$. Rasyid et al. and Ott et al. study found that more than $40 \%$ of acute ischemic stroke patients had increased blood viscosity $[17,18]$ Blood viscosity also tends to be higher in certain populations such as elderly, smokers, hypertensive people, diabetic people, patients with ischemic heart disease, and dyslipidemic patients $[11,12,19,20]$. Blood hyperviscosity contributes to the severity of the ischemic stroke outcomes $[14,18]$. Blood hyperviscosity in the penumbra can decrease cerebral blood flow and lead to more severe ischemia [21]. Blood viscosity can be measured by the long-waiting laboratory examination or instantly by digital microcapillary (DM) instrument created by Al Rasyid in 2014 [22].

Outcome of stroke patient can be evaluated using the National Institutes of Health Stroke Scale (NIHSS) and modified Rankin Scale (mRS). NIHSS evaluates the patient's impairment. NIHSS can measure severity of symptoms related with brain infarction and evaluate post-stroke neurologic deficit. Higher NIHSS score represents more severe impairment [23]. mRS evaluates the patient's disability. mRS measures patient's independency poststroke [24]. This study aimed to investigate the effect of blood viscosity in determining the outcomes of acute ischemic stroke using NIHSS and mRS evaluation.

\section{MATERIALS AND METHODS}

\section{Subjects and procedures}

This cohort study used consecutive sampling method of acute ischemic stroke patients admitted to the Emergency Department or Neurology Outpatient Department in Cipto Mangunkusumo General Hospital between January 2017 and April 2017. Inclusion criteria for this study were an adult (aged 19-80 y old) ischemic stroke patients with stroke symptom onset within $72 \mathrm{~h}$. Patients with posterior circulation infarct (POCI) or total anterior circulation infarct (TACI) were excluded from this study. Patients included in this study were those who had the stroke for the first time. Patients with previous stroke history or/and had received intravenous/intra-arterial thrombolysis before were excluded. Patients who had chronic kidney disease, sepsis, malignancy, congestive heart failure, liver failure, or severe dehydration were also excluded; hence these factors could potentially influence the outcome of the therapy. Patients who consumed corticosteroid and diuretic were also excluded from this study.

History taking, physical examination, and National Institute of Health Stroke Scale (NIHSS) score were taken on the first day patient came to the hospital. NIHSS score ranges between $0-42$. Laboratory examination including blood urea, creatinine, sodium, potassium, and glucose level were performed on the patients. Blood viscosity of the patient was also investigated using digital microcapillary (DM) instrument. Brain imaging using commuted topography (CT) scan without contrast was also performed on the patients to establish the ischemic stroke diagnosis.

NIHSS score of patients was taken again on day 7 hospitalized. Patients who had returned home before day-7-hospitalization were 
advised to make an outpatient visit to Neurology Outpatient Department on day 7 post first-day-visit. NIHSS day-7 score for those patients was collected at that visit. All patients were told to make an outpatient visit on day 30 post first-day-visit to collect modified Rankin Scale (mRS) score. mRS score can range from 0 (no symptoms) to 6 (dead). NIHSS day-7 and mRS day-30 score were the outcomes evaluated in this study.

Patients with NIHSS score increased $\geq 1$ on day-7-evaluation were categorized as having a poorer neurologic deficit. Patients who had mRS day-30 score 0-2 were categorized as having good outcome while those who had score $>2$ were categorized as having poor outcome.

This study also evaluated the possibility of other risk factors in affecting the outcomes of ischemic stroke. Risk factors investigated consisted of age, sex, hypertension, hyperglycemia, atrial fibrillation, dehydration state, and type of stroke (partial anterior circulation infarct [PACI] or lacunar infarct [LACI]).

This study had been approved by Committee Ethics of Faculty of Medicine University of Indonesia/Cipto Mangunkusumo General Hospital with approval number 281/UN2/F1/ETIK/2017. All patients gave informed consent. Identity and data of all patients were held confidential.

\section{Statistical analysis}

Data were analyzed statistically using SPSS version 20. Most data were presented as categorical data. Chi-square test or Fisher's exact test was performed to identify the significance of blood viscosity as a determining factor of ischemic stroke outcomes. The possibility of other risk factors in influencing outcomes of stroke was analyzed using logistic regression.

\section{RESULTS}

There were 44 ischemic stroke patients submitted to Emergency Department or Neurology Outpatient Department in Cipto Mangunkusumo General Hospital between January 2017 and April 2017 who met the eligibility criteria and were willing to participate in this study. Subjects of this study: $56.8 \%$ were male; $27.3 \%$ aged $>65$ y old; $77.3 \%$ were hypertensive; $40.9 \%$ were hyperglycemic; $6.8 \%$ had atrial fibrillation; and $47.7 \%$ had dehydration. Most patients (90.9\%) had a lacunar infarct (LACI) type of stroke. No patient had fever and $88.6 \%$ patients admitted to the hospital on the first day of stroke symptoms onset. Fig. 1 showed that $88.6 \%$ of the patients had blood hyperviscosity.

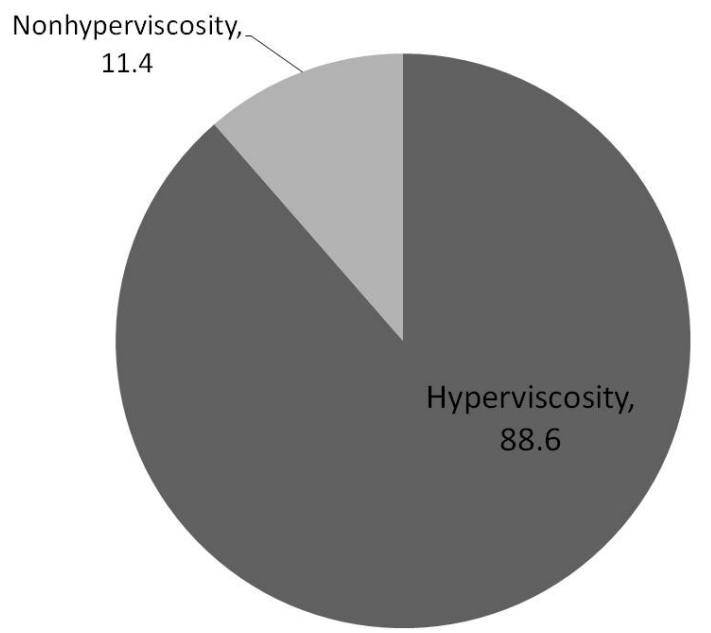

Fig. 1: Pie chart showing the percentage of blood hyperviscosity and nonhyperviscosity in the patients

There were 39 patients with blood hyperviscosity while there were only 5 patients with normal blood viscosity. There was no significant proportional difference among other variables such as age, sex, hydration state, blood pressure level, blood glucose level, atrial fibrillation, stroke subtype, and stroke onset towards blood viscosity as described in table 1.

Table 1: Baseline demographic and clinical characteristics of hyperviscosity and nonhyperviscosity group

\begin{tabular}{|c|c|c|c|c|}
\hline & Hyperviscosity, n (\%) & Non-hyperviscosity n (\%) & p score* & Relative risk (RR) $(95 \% \mathrm{CI})$ \\
\hline \multicolumn{5}{|l|}{ Age, $y$} \\
\hline$\leq 65$ & $27(84.4)$ & $5(15.6)$ & 0.301 & $1.185(1.021-1.376)$ \\
\hline$>65$ & $12(100.0)$ & $0(0.0)$ & & \\
\hline \multicolumn{5}{|l|}{ Sex } \\
\hline Male & $23(92.0)$ & $2(8.0)$ & 0.638 & $1.093(0.871-1.370)$ \\
\hline Female & $16(84.2)$ & $3(15.8)$ & & \\
\hline \multicolumn{5}{|l|}{ Fever } \\
\hline Yes & $0(0.0)$ & $0(0.0)$ & - & - \\
\hline No & $39(88.6)$ & $5(11.4)$ & & \\
\hline \multicolumn{5}{|c|}{ Dehydration } \\
\hline Yes & $20(95.2)$ & $1(4.8)$ & 0.348 & $1.153(0.934-1.423)$ \\
\hline No & $19(82.6)$ & $4(17.4)$ & & \\
\hline \multicolumn{5}{|c|}{ Hypertension } \\
\hline Yes & $30(88.2)$ & $4(11.8)$ & 1.000 & $0.980(0.771-1.247)$ \\
\hline No & $9(90.0)$ & $1(10.0)$ & & \\
\hline \multicolumn{5}{|c|}{ Hyperglycemia } \\
\hline Yes & $14(77.8)$ & $4(22.2)$ & 0.142 & $0.809(0.625-1.048)$ \\
\hline No & $25(96.2)$ & $1(3.8)$ & & \\
\hline \multicolumn{5}{|c|}{ Atrial fibrillation } \\
\hline Yes & $3(100.0)$ & $0(0.0)$ & 1.000 & $1.139(1.016-1.277)$ \\
\hline No & $36(87.8)$ & $5(12.2)$ & & \\
\hline \multicolumn{5}{|c|}{ Stroke subtype } \\
\hline PACI & $3(75.0)$ & $1(25.0)$ & 0.394 & $0.833(0.469-1.481)$ \\
\hline LACI & $36(90.0)$ & $4(10.0)$ & & \\
\hline \multicolumn{5}{|c|}{ Stroke onset } \\
\hline Day 1 & $34(87.2)$ & $5(12.8)$ & 1.000 & $0.872(0.773-0.983)$ \\
\hline Day 2-3 & $5(100.0)$ & $0(0.0)$ & & \\
\hline
\end{tabular}

*Fisher's exact test. PACI: partial anterior circulation infarct, LACI: lacunar circulation infarct 


\section{Outcomes of patients}

On day-7-evaluation, only 4 patients had a poorer neurologic deficit than the first-day-evaluation -having increased National Institute of
Health Stroke Scale (NIHSS) score $\geq 1$. NIHSS score on $90.9 \%$ patients did not increase. Most patients (81.8\%) in this study also had good outcome on day-30-evaluation with modified Rankin Scale (mRS) score 0-2 as described in fig. 2.

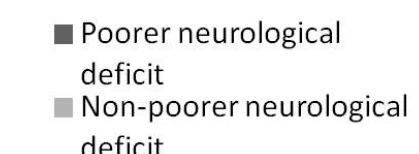
deficit

\section{Poor outcome \\ Good outcome}

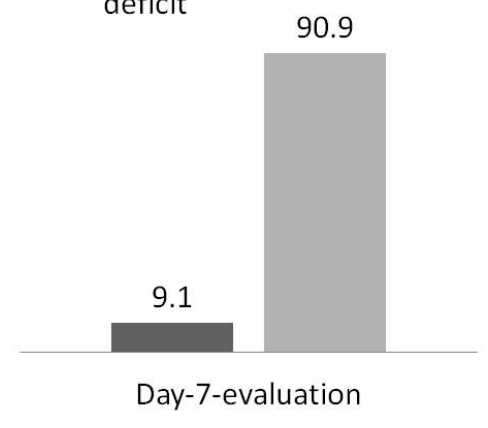

Fig. 2: Column chart showing outcomes of the patients on day-7 and day-30 evaluation

\section{Factors affecting outcomes of patients}

Based on the bivariate analysis performed, partial anterior circulation infarct (PACI) gave a significant contribution to the poorer neurologic deficit (RR=10.000; 95\% CI: 1.885-53.061; $p=0.036$, table 2). Proportion of poorer neurologic deficit in PACI subtype was higher than in lacunar infarct (LACI), $50.0 \%$ and $5.0 \%$, respectively. Normal hydration state contributed to non-poorer neurologic deficit (RR=0.810; 95\% CI: 0.658 $0.996 ; p=0.044$, table 2). There were no patients with normal hydration state experienced poorer neurologic deficit on day-7-evaluation.

Table 2: Factors affecting NIHSS score on day-7-evaluation

\begin{tabular}{|c|c|c|c|c|}
\hline & $\begin{array}{l}\text { Poorer neurologic deficit } \\
\text { n (\%) }\end{array}$ & $\begin{array}{l}\text { Non-poorer neurologic deficit } \\
\text { n (\%) }\end{array}$ & p score* & Relative risk (RR) $(95 \% \mathrm{CI})$ \\
\hline \multicolumn{5}{|c|}{ 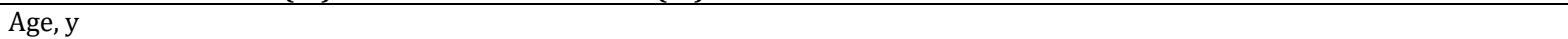 } \\
\hline$\leq 65$ & $1(3.1)$ & 31 (96.9) & 0.056 & $8.000(0.919-69.629)$ \\
\hline$>65$ & $3(25.0)$ & $9(75.0)$ & & \\
\hline \multicolumn{5}{|l|}{ Sex } \\
\hline Male & $2(8.0)$ & $23(92.0)$ & 1.000 & $0.760(0.117-4.916)$ \\
\hline Female & $2(10.5)$ & $17(89.5)$ & & \\
\hline \multicolumn{5}{|l|}{ Fever } \\
\hline Yes & $0(0.0)$ & $0(0.0)$ & - & - \\
\hline No & $4(9.1)$ & $40(90.9)$ & & \\
\hline \multicolumn{5}{|c|}{ Dehydration } \\
\hline Yes & $4(19.0)$ & $17(81.0)$ & 0.044 & $0.810(0.658-0.996)$ \\
\hline No & $0(0.0)$ & $23(100.0)$ & & \\
\hline \multicolumn{5}{|c|}{ Hypertension } \\
\hline Yes & $3(8.8)$ & $31(91.2)$ & 1.000 & $0.882(0.103-7.579)$ \\
\hline No & $1(10.0)$ & $9(90.0)$ & & \\
\hline \multicolumn{5}{|c|}{ Hyperglycemia } \\
\hline Yes & $2(11.1)$ & $16(88.9)$ & 1.000 & $1.444(0.224-9.330)$ \\
\hline No & $2(7.7)$ & $24(92.3)$ & & \\
\hline \multicolumn{5}{|c|}{ Atrial fibrillation } \\
\hline Yes & $1(33.3)$ & $2(66.7)$ & 0.254 & $4.556(0.657-31.572)$ \\
\hline No & $3(7.3)$ & $38(92.7)$ & & \\
\hline \multicolumn{5}{|c|}{ Stroke subtype } \\
\hline PACI & $2(50.0)$ & $2(50.0)$ & 0.036 & $10.000(1.885-53.061)$ \\
\hline LACI & $2(5.0)$ & $38(95.0)$ & & \\
\hline \multicolumn{5}{|c|}{ Stroke onset } \\
\hline Day 1 & $3(7.7)$ & $36(92.3)$ & 0.394 & $1.154(0.738-1.805)$ \\
\hline Day 2-3 & $1(20.0)$ & $4(80.0)$ & & \\
\hline
\end{tabular}

*Fisher's exact test. PACI: partial anterior circulation infarct, LACI: lacunar circulation infarct

Multivariate analysis was performed to identify adjusted relative risk (adjusted RR) of variables fulfilling chi-square test's conditions with $p$ score $<0.250$ (i.e. age and stroke subtype). Logistic regression analysis was used. Result of the analysis showed that patients with PACI had a likelihood of 18.089 times to have a poorer neurologic deficit on day-7- evaluation than patients with LACI (adjusted RR=18.089; 95\% CI: 1.121 291.970; $\mathrm{p}=0.041$, table 3). Half of the patients (50.0\%) with PACI had poorer neurologic deficit while only $5.0 \%$ patients with LACI had poorer neurologic deficit. Elderly patients (aged $>65 \mathrm{y}$ old) had a likelihood of 9.908 times to have poorer neurologic deficit than those that younger. 
Table 3: Determining factors of poorer neurologic deficit

\begin{tabular}{|c|c|c|c|c|}
\hline & $\begin{array}{l}\text { Poorer neurologic deficit } \\
\text { n (\%) }\end{array}$ & $\begin{array}{l}\text { Non-poorer neurologic deficit } \\
\text { n (\%) }\end{array}$ & $p$ score & Adjusted RR* (95\% CI) \\
\hline \multicolumn{5}{|c|}{ Stroke subtype } \\
\hline PACI & $2(50.0)$ & $2(50.0)$ & 0.041 & $18.089(1.121-291.970)$ \\
\hline LACI & $2(5.0)$ & $38(95.0)$ & & \\
\hline \multicolumn{5}{|l|}{ Age, $y$} \\
\hline$>65$ & $3(25.0)$ & $9(75.0)$ & 0.090 & $9.908(0.698-291.702)$ \\
\hline$\leq 65$ & $1(3.1)$ & $31(96.9)$ & & \\
\hline
\end{tabular}

*Logistic regression analysis. PACI: partial anterior circulation infarct, LACI: lacunar circulation infarct

PACI also significantly contributed to poor outcome on day-30patients with PACI had poor outcome while only $10.0 \%$ of patients evaluation ( $R R=10.000$; 95\% CI: 3.947-25.337; $p=0.001$, table 4). All with LACI had poor outcome.

Table 4: Factors affecting mRS score on day-30-evaluation

\begin{tabular}{|c|c|c|c|c|}
\hline & Poor outcome, n (\%) & Good outcome, n (\%) & p score* & Relative risk (RR) $(95 \% \mathrm{CI})$ \\
\hline \multicolumn{5}{|l|}{ Age, y } \\
\hline$\leq 65$ & $5(15.6)$ & $27(84.4)$ & 0.663 & $1.600(0.450-5.688)$ \\
\hline$>65$ & $3(25.0)$ & $9(75.0)$ & & \\
\hline \multicolumn{5}{|l|}{ Sex } \\
\hline Male & $4(16.0)$ & $21(84.0)$ & 0.710 & $0.760(0.218-2.655)$ \\
\hline Female & $4(21.1)$ & $15(78.9)$ & & \\
\hline \multicolumn{5}{|l|}{ Fever } \\
\hline Yes & $0(0.0)$ & $0(0.0)$ & - & - \\
\hline No & $8(18.2)$ & $36(81.8)$ & & \\
\hline \multicolumn{5}{|c|}{ Dehydration } \\
\hline Yes & $4(19.0)$ & $17(81.0)$ & 1.000 & $1.095(0.313-3.835)$ \\
\hline No & $4(17.4)$ & $19(82.6)$ & & \\
\hline \multicolumn{5}{|c|}{ Hypertension } \\
\hline Yes & $5(14.7)$ & $29(85.3)$ & 0.355 & $0.490(0.141-1.704)$ \\
\hline No & $3(30.0)$ & $7(70.0)$ & & \\
\hline \multicolumn{5}{|c|}{ Hyperglycemia } \\
\hline Yes & $2(11.1)$ & $16(88.9)$ & 0.439 & $0.481(0.109-2.122)$ \\
\hline No & $6(23.1)$ & $20(76.9)$ & & \\
\hline \multicolumn{5}{|c|}{ Atrial fibrillation } \\
\hline Yes & $1(33.3)$ & $2(66.7)$ & 0.461 & $1.952(0.344-11.087)$ \\
\hline No & $7(17.1)$ & $34(82.9)$ & & \\
\hline \multicolumn{5}{|c|}{ Stroke subtype } \\
\hline PACI & $4(100.0)$ & $0(0.0)$ & 0.001 & $10.000(3.947-25.337)$ \\
\hline LACI & $4(10.0)$ & $36(90.0)$ & & \\
\hline \multicolumn{5}{|c|}{ Stroke onset } \\
\hline Day 1 & $7(17.9)$ & $32(82.1)$ & 1.000 & $1.026(0.646-1.628)$ \\
\hline Day 2-3 & $1(20.0)$ & $4(80.0)$ & & \\
\hline
\end{tabular}

*Fisher's exact test. PACI: partial anterior circulation infarct, LACI: lacunar circulation infarct

Table 5: Outcomes of patients with blood hyperviscosity

\begin{tabular}{|c|c|c|c|c|}
\hline & Hyperviscosity, n (\%) & Non-hyperviscosity, n (\%) & $p$ score* & Relative risk (RR) (95\% CI) \\
\hline \multicolumn{5}{|l|}{ NIHSS day-7 } \\
\hline Poorer neurologic deficit & $4(10.3)$ & $0(0.0)$ & 1.000 & $0.897(0.807-0.998)$ \\
\hline $\begin{array}{l}\text { Non-poorer neurologic deficit } \\
\text { mRS day- } 30\end{array}$ & 35 (89.7) & $5(100.0)$ & & \\
\hline Poor outcome & $7(17.9)$ & $1(20.0)$ & 1.000 & $0.897(0.137-5.864)$ \\
\hline Good outcome & $32(82.1)$ & $4(80.0)$ & & \\
\hline
\end{tabular}

*Fisher's exact test. NIHSS: National Institute of Health Stroke Scale, mRS: modified Rankin Scale

\section{Impact of blood hyperviscosity on ischemic stroke outcomes}

Blood hyperviscosity significantly did not give contribution neither to the poorer neurologic deficit on day-7-evalution nor poor outcome on day-30-evaluation as described in table 5 .

\section{DISCUSSION}

There were 44 ischemic stroke patients participated in this study. The patients were gathered consecutively on the outpatient visit or emergency department admission. $72.7 \%$ of patients aged $\leq 65 \mathrm{y}$ old while $27.3 \%$ aged $>65 \mathrm{y}$ old. These findings do not really correspond with RISKESDAS 2018 stated that $45.3 \%$ people aged $65-74$ y old had stroke and $50.2 \%$ people aged $\geq 75$ y old had stroke [9]. These result probably caused by sampling method of this study. This study used consecutive sampling method which gathered subjects met eligibility criteria in the period of January $1^{\text {st }}$ to April $31^{\text {st }} 2017$.

It was found that all patients aged $>65$ y old had blood hyperviscosity. This finding corresponds with Emril et al. study stated that old age was associated with an increase of blood 
viscosity. This may be due to the decrease of blood plasma volume in elderly which causes increased hematocrit [25].

Most patients $(56.8 \%)$ were male. This finding corresponds with Harris et al. and Rasyid et al. study which found the percentage of male ischemic stroke patients were higher than female, $59.1 \%$ vs $40.9 \%$, and $63 \%$ vs $36 \%$, respectively [26, 27]. Harris et al. and Rasyid et al. study both took place in Cipto Mangunkusumo General Hospital/Rumah Sakit Cipto Mangunkusumo (RSCM), similar with this study. In this study, proportion of blood hyperviscosity in male was higher than in female, $92.0 \%$ and $84.2 \%$, respectively. These findings may be caused by higher frequency of stroke risks in male population such as smoking, hypertension, dyslipidemia, coronary artery disease (CAD), and atrial fibrillation $[28,29]$. Smoking can increase blood viscosity by causing decrease of erythrocyte deformability and increase of erythrocyte aggregation [30].

Approximately half of the patients (47.7\%) had dehydration. This finding corresponds with Fadhly et al. study on ischemic stroke patients treated in RSCM during 2014 stated that 51\% of the patients had dehydration [31]. Schrock et al. found that $36 \%$ patients with acute ischemic stroke had dehydration [32]. Rowat et al. reported that $29 \%$ of acute ischemic stroke patients had dehydration on the first-day hospitalized [33]. Most patients with dehydration in this study had blood hyperviscosity (95.2\%). This finding corresponds with studies stated that dehydration could increase blood viscosity [34-36].

Percentage of stroke risk factors i.e. hypertension, hyperglycemia, and atrial fibrillation was $77.3 \%, 40.9 \%$, and $6.8 \%$, consecutively. This finding is consistent with RISKESDAS 2013 stated that hypertension was the principal risk factor for stroke [8]. Percentages of those with blood hyperviscosity in hypertensive patients, hyperglycemic patients, and patients with atrial fibrillation in this study were high: $88.2 \%, 77.8 \%$, and $100.0 \%$, consecutively. These findings correspond with Kuriakose et al. study stated that blood hyperviscosity was present in most patients with stroke risk factors such as smoking, diabetes mellitus, dyslipidemia, and heart disease [37]. Rasyid stated that hypertension and diabetes mellitus can lead to blood hyperviscosity [30]. Blood viscosity increases on hypertensive patients [17]. In patients with diabetes mellitus, an increase of blood viscosity is caused by microangiopathy and/or macroangiopathy. A study showed that there was a significant correlation between increase of $\mathrm{HbA1C}$ level and fibrinogen level, erythrocyte aggregation, and blood viscosity $(\mathrm{p}<0.001)[11]$.

Stroke subtype was based on Bamford's ischemic stroke classification: total anterior circulation infarct (TACI); partial anterior circulation infarct (PACI); lacunar circulation infarct (LACI); and posterior circulation infarct (POCI) [38]. Ischemic stroke patients with TACI and POCI subtype were excluded in this study leaving only patients with PACI and LACI stroke subtype. Most patients (90.9\%) had LACI. This result is consistent with Harris et al. study on 3627 ischemic stroke patients in Indonesia uncovered that $45.07 \%$ of those patients had LACI stroke subtype [39]. Both patients with PACI and patients with LACI had high percentage of blood hyperviscosity, $75.0 \%$ and $90.0 \%$, respectively. These results can be explained by Rasyid stated that blood hyperviscosity was present in most ischemic stroke cases [12, 22].

Stroke patients selected in this study were those with symptoms onset within $72 \mathrm{~h}$, based on study by Rasyid [22]. Onset of stroke then categorized as: on the first day (day 1); and on the second or the third day (day 2-3). Most patients (88.6\%) came to the hospital on the first day of onset. This finding corresponds with Harris et al. study in which $91 \%$ patients came to the hospital within $24 \mathrm{~h}$ of symptoms onset [40]. All patients who came to the hospital on day 2-3 had blood hyperviscosity in this study. This may be due to small number of patients who came to the hospital on day 2 or 3 of stroke onset $(n=5)$.

Most patients had favorable outcomes evaluated both on day 7 and day 30. On day-7-evaluation, $90.9 \%$ patients did not have poorer neurologic deficit. On day-30-evaluation, $81.8 \%$ had a good outcome with the modified Rankin Scale (mRS) score 0-2. This study followed an acute ischemic stroke outcome evaluation method by Rasyid and Smith et al. $[22,41]$. Also following Rasyid study, mRS score $0-2$ were classified as good outcome while score $>2$ were classified as poor outcome [22].

Fisher's exact test was performed to compare percentage between variables. Based on test performed, there was a significant proportional difference between PACI and LACI towards towards poorer neurologic deficit on day-7-evaluation. Logistic regression analysis then performed. The analysis result showed that patients with PACI had likelihood of 18.089 times to have poorer neurologic deficit than patients with LACI. PACI also significantly correlated with poor outcome on day-30-evaluation. Patients with PACI had likelihood of 10 times to have poor outcome on day-30-evaluation than patients with LACI. These findings were consistent with Mohr et al. study stated that survival rate on patients with LACI was significantly better than another subtypes of stroke [42]. Sprigg study on 1484 acute ischemic stroke patients found that patients with LACI tend to have faster clinical improvement than patients with other stroke subtypes. Patients who have fast clinical improvement will go through early mobilization thus prevent them from having complications such as pneumonia and thrombosis [43].

Nondehydration significantly contributed to non-poorer neurologic deficit on day-7-evaluation ( $\mathrm{RR}=0.810 ; 95 \% \mathrm{CI}$ : 0.658-0.996; $\mathrm{p}=0.044$ ). All patients with normal hydration state had a non-poorer neurologic deficit. Although, both dehydration and nondehydration patients mostly had good outcome on day-30-evaluation, $81.0 \%$ and $82.6 \%$, respectively. This finding is different with $\mathrm{Wu}$ et al. study found that good mRS outcome was significantly lower in dehydration group of acute ischemic stroke patients $(p=0.012)$. Multivariate analysis $\mathrm{Wu}$ et al. performed then showed that dehydration patients had a smaller likelihood of achieving good mRS outcome (score $\leq 2$ ) than nondehydration patients ( $R R=0.46$; $\mathrm{p}=0.004$ ) [44]. Rowat et al. study found that dehydration was significantly related with poor outcomes such as death and physical independency $(p=0.0001)$ [33]. Dehydration can reduce cerebral blood flow (CBF) and cerebral perfusion pressure (CPP) thus worsen ongoing ischemia and eventually lead to worse outcomes [34-36].

Quarter of patients $(25.0 \%)$ aged $>65 \mathrm{y}$ old had poorer neurologic deficit on day-7-evaluation while only $3.1 \%$ patients aged $\leq 65$ y old had poorer neurologic deficit. Elderly patients (aged $>65$ y old) had likelihood of eight times to have poorer neurologic deficit than younger patients $(\mathrm{RR}=8.000 ; 95 \% \mathrm{CI}$ : 0.919-69.629; $\mathrm{p}=0.056)$. Multivariate analysis performed then showed that patients aged $>65$ $\mathrm{y}$ old had tendency to have poorer neurologic deficit on day-7evaluation 9.908 times than patients aged $\leq 65$ y old. Thrift et al. study stated that crude death rate and crude incidence rate of stroke were both positively correlated with the proportion of aged $\geq 65 \mathrm{y}$ population [45]. This is most likely due to the prognosis of cerebrovascular disease relies on blood viscosity $[46,47]$. Blood viscosity is increased in elderly population $[30,48]$. Blood hyperviscosity can reduce cerebral blood flow thus causes more severe brain tissue hypoperfusion [46, 47].

Blood viscosity is a major risk factor for ischemic heart disease and stroke $[17,49]$. Autonomic activity, blood viscosity, and endothelial dysfunction determine the peripheral resistance. Peripheral resistance affects systemic blood pressure. Blood flow of the brain is determined by CPP that results from reduction of systemic blood pressure and intracranial pressure. Decrease in CBF will result in brain cells death. Hyperviscosity may lead to more brain cells death thus resulting in poorer outcome of ischemic stroke [50]. In this study, it was found that all patients with normal blood viscosity did not have poorer neurologic deficit on day-7-evaluation. Despite blood viscosity had been stated taking a part in determining outcomes of ischemic stroke in previous studies before, there was no significant difference of either day-7-outcome or day-30-outcome on patients with hyperviscosity and patients with nonhyperviscosity in this study. This is probably caused by small number of subjects in this study and there was unbalanced number of the subject between hyperviscosity and nonhyperviscosity group. Another limitation of this study is that outcome of patients on day 90 post-thrombolysis could not be evaluated even though it is the standard measurement of acute ischemic stroke patients' functional outcome [51]. 


\section{CONCLUSION}

Results of this study suggest that blood viscosity plays a role in determining the outcomes of ischemic stroke. Most acute ischemic stroke patients had blood hyperviscosity. All patients with normal blood viscosity did not have a poorer neurologic deficit on day-7evaluation. In conclusion, blood viscosity is a determining factor of ischemic stroke outcomes evaluated with NIHSS and mRS on day 7 and day 30 post-thrombolysis.

\section{ACKNOWLEDGMENT}

The authors thank all the party involved in this study.

\section{AUTHORS CONTRIBUTIONS}

All the authors have contributed equally

\section{CONFLICT OF INTERESTS}

The authors declare that there is no conflict of interest

\section{REFERENCES}

1. WHO. Disease burden and mortality estimates. WHO. Available from:

http://www.who.int/healthinfo/global_burden_disease/estim ates/en/. [Last accessed on 24 Apr 2019]

2. Johnson W, Onuma O, Owolabi M, Sachdev S. WHO | Stroke: a global response is needed. WHO. Available from: http://www.who.int/bulletin/volumes/94/9/16-181636/en/. [Last accessed on 24 Apr 2019].

3. Feigin VL, Norrving B, Mensah GA. Global burden of stroke. Circ Res 2017;120:439-48.

4. Katan M, Luft A. Global burden of stroke. Semin Neurol 2018;38:208-11.

5. Venketasubramanian N, Yoon BW, Pandian J, Navarro JC. Stroke epidemiology in South, East, and South-East Asia: a review. J Stroke 2017;19:286-94.

6. Stroke Statistics | Internet Stroke Center [Internet]. Available from: http://www.strokecenter.org/patients/about-stroke/ stroke-statistics/. [Last accessed on 26 Apr 2019]

7. Mozaffarian D, Go AS, Arnett DK, Blaha MJ, Cushman M, Das SR, et al. Heart disease and stroke statistics-2016 update: a report from the American Heart Association. Circulation 2016;133:e38-360.

8. Badan Penelitian dan Pengembangan Kesehatan. Riset kesehatan dasar: riskesdas. Jakarta: Badan Penelitian dan Pengembangan Kesehatan; 2013.

9. Badan Penelitian dan Pengembangan Kesehatan. Hasil Riskesdas. Badan Penelitian dan Pengembangan Kesehatan; 2018.

10. Wood JH, Kee DB. Hemorheology of the cerebral circulation in stroke. Stroke 1985;16:765-72.

11. Uddin MJ, Mondol BA, Ahmed S, Ullah AA, Jabbar M, Mohammad QD. Smoking and ischemic stroke. Bangladesh J Neurosci 1970;24:50-4.

12. Rasyid A, Misbach J, Purba JS, Timan IS, Sukrisman L, Mansyur $\mathrm{M}$, et al. The role of a novel digital microcapillary instrument in detecting blood and plasma hyperviscosity. Acta Medica Indones 2014;46:7.

13. Lechner H, Ott E, Bertha G. Therapeutical aspects of cerebrovascular disease. Eur Neurol 1983;22:74-7.

14. Ahmed HS, Hu CJ, Paczynsky R, Hsu CY. Pathophysiology of ischemic injury. In: Fisher M. editor. Stroke therapy. Boston: Butterworth-Heinemann; 2001. p. 25-32.

15. Szapary L, Horvath B, Marton Z, Alexy T, Demeter N, Szots M, et al. Hemorheological disturbances in patients with chronic cerebrovascular diseases. Clin Hemorheol Microcirc 2004;31:1-9.

16. Meliala C, Nuradyo D, Suryatmojo B. Hiperviskositas sebagai faktor risiko stroke infark di RSUP Dr. Sardjito FK UGM Yogyakarta [Thesis]. [Yogyakarta]: Gadjah Mada University; 1996.

17. Rasyid A, Nuradyo D, Sutarni S. Realibilitas dan validitas mikrokapiler hematokrit pada pemeriksaan viskositas darah penderita stroke iskemik akut dan stroke infark. Neuro Sains 2000;1:97-102.

18. Ott E, Fazekas F, Tschinkel M, Bertha G, Lechner H. Rheological aspects of cerebrovascular disease. Eur Neurol 1983;22:35-7.

19. McDonald K. Effect of hematocrit and colloid-induced changes in blood viscosity on renal hemodynamics and renin release in the dog. Circ Res 1977;40:112-22.

20. Le Devehat C, Vimeux M, Khodabandehlou T. Blood rheology in patients with diabetes mellitus. Clin Hemorheol Microcirc 2004;30:297-300.

21. Thomas DJ. Whole blood viscosity and cerebral blood flow. Stroke 1982;13:285-7.

22. Rasyid A. Efektivitas mikrokapiler digital sebagai alat ukur nilai viskositas darah untuk prediksi prognosis stroke iskemik akut [Dissertation]. [Jakarta]: University of Indonesia; 2014.

23. Lansberg MG, O'Donnell MJ, Khatri P, Lang ES, Nguyen Huynh MN, Schwartz NE, et al. Antithrombotic and thrombolytic therapy for ischemic stroke: Antithrombotic therapy and prevention of thrombosis. $9^{\text {th }}$ ed: American College of Chest Physicians Evidence-Based Clinical Practice Guidelines. Chest 2012;141 Suppl 2:e601S-e636S.

24. Salter K, Jutai J, Zettler L, Moses M, McClure A, Mays R, et al. Outcome measures in stroke rehabilitation. Evidence-Based Rev Stroke Rehabilitation London; 2005. p. 1-56.

25. Emril RD, Vivien P, Mayza A, Rasyid A. Elevated blood viscosity in the population aged $60 \mathrm{y}$ up. Neuronal 2005;22:4-6.

26. Harris S, Sungkar S, Rasyid A, Kurniawan M, Mesiano T, Hidayat R. TOAST subtypes of ischemic stroke and its risk factors: a hospital-based study at cipto mangunkusumo hospital, Indonesia. Stroke Res Treat 2018;1-6. https://doi.org/ $10.1155 / 2018 / 9589831$

27. Rasyid A, Harris S, Nurhayat E, Prihartono J. Pentoxifylline in acute ischemic stroke patients with blood hyperviscosity. Int J Appl Pharm 2018;10:307.

28. Palm F, Urbanek C, Wolf J, Buggle F, Kleemann T, Hennerici MG, et al. Etiology, risk factors and sex differences in ischemic stroke in the Ludwigshafen Stroke Study, a population-based stroke registry. Cerebrovasc Dis 2012;33:69-75.

29. Martin Schild S, Samai A. Sex differences in predictors of ischemic stroke: current perspectives. Vasc Health Risk Manag 2015;11:427-36.

30. Rasyid A. The role of blood viscosity in acute ischemic stroke. Neuronal 2014;31:192-6.

31. Fadhly ZIK, Meisadona G, Kurniawan M, Mesiano T, Harris S. Does hydration status affect the outcome of stroke? A preliminary study. In: 57th Annual World Congress of International College of Angiology. Jakarta; 2015.

32. Schrock JW, Glasenapp M, Drogell K. Elevated blood urea nitrogen/creatinine ratio is associated with poor outcome in patients with ischemic stroke. Clin Neurol Neurosurg 2012;114:881-4.

33. Rowat A, Graham C, Dennis M. Dehydration in hospitaladmitted stroke patients: detection, frequency, and association. Stroke 2012;43:857-9.

34. Lin LC, Lee JD, Hung YC, Chang CH, Yang JT. Bun/creatinine ratio-based hydration for preventing stroke-in-evolution after acute ischemic stroke. Am J Emerg Med 2014;32:709-12.

35. Ock S, Jo S, Lee JB, Jin Y, Jeong T, Yoon J, et al. Comprehensive interpretation of hyperglycemia and hyperosmolality on the clinical outcomes among ischemic stroke patients. Am J Emerg Med 2016;34:2343-50.

36. Vlastos GA, Tangney CC, Rosenson RS. Effects of hydration on blood rheology. Clin Hemorheol Microcirc 2003;28:41-9.

37. KS Kuriakose C, M NS, Tharakan NS, R SK. A prospective study of clinical profile of stroke in a tertiary care hospital. Asian J Pharm Clin Res 2016;9:178.

38. Sandercock P, Bamford J, Dennis M, Burn J, Slattery J, Jones L, et al. Atrial fibrillation and stroke: prevalence in different types of stroke and influence on early and long term prognosis (Oxfordshire community stroke project). $\mathrm{Br}$ Med J 1992;305:1460-5.

39. Harris S, Kurniawan M, Rasyid A, Mesiano T, Hidayat R. Cerebral small vessel disease in Indonesia: Lacunar infarction 
study from Indonesian Stroke Registry 2012-2014. SAGE Open Med 2018;6:2050312118784312.

40. Harris S, Rasyid A, Nurhayati E, Prihartono J. Selected benefits of pentoxifylline in acute ischemic stroke management: consideration of risk factors. In: Proceedings of the Health Science International Conference (HSIC 2017). Malang, Indonesia: Atlantis Press; 2017. Available from: http://www.atlantis-press.com/php/paperdetails.php?id=25885884. [Last accessed on 24 Apr 2019]

41. Smith CJ, Emsley HC, Gavin CM, Georgiou RF, Vail A, Barberan EM, et al. Peak plasma interleukin-6 and other peripheral markers of inflammation in the first week of ischaemic stroke correlate with brain infarct volume, stroke severity and longterm outcome. BMC Neurol 2004;4. Available from: http://bmcneurol.biomedcentral.com/articles/10.1186/14712377-4-2. [Last accessed on 24 Apr 2019]

42. Mohr JP. Stroke: pathophysiology, diagnosis, and management. Philadelphia, PA: Elsevier/Saunders; 2011.

43. Sprigg N, Gray LJ, Bath PMW, Lindenstrøm E, Boysen G, De Deyn PP, et al. Stroke severity, early recovery and outcome are each related with the clinical classification of stroke: Data from the 'Tinzaparin in Acute Ischaemic Stroke Trial' (TAIST). J Neurol Sci 2007;254:54-9.
44. Wu FF, Hung YC, Tsai YH, Yang JT, Lee TH, Liow CW, et al. The influence of dehydration on the prognosis of acute ischemic stroke for patients treated with tissue plasminogen activator. BMC Cardiovasc Disord 2017;17. Available from: http://bmccardiovascdisord.biomedcentral.com/articles/10.1 186/s12872-017-0590-6. [Last accessed on 24 Apr 2019]

45. Thrift AG, Thayabaranathan T, Howard G, Howard VJ, Rothwell PM, Feigin VL, et al. Global stroke statistics. Int J Stroke 2017;12:13-32.

46. Lowe GDO. Virchow's triad revisited: Abnormal flow. Pathophysiol Haemost Thromb 2003;33:455-7.

47. Tomiyama Y, Brian JE, Todd MM. Plasma viscosity and cerebral blood flow. Am J Physiol Heart Circ Physiol 2000;279:H1949-54.

48. Wang Y, Lim LL, Levi C, Heller RF, Fisher J. Influence of admission body temperature on stroke mortality. Stroke 2000;31:404-9.

49. Coppola Null, Caserta Null, De Lucia D Null, Guastafierro Null, Grassia Null, Coppola Null, et al. Blood viscosity and aging. Arch Gerontol Geriatr 2000;31:35-42.

50. Caplan LR. Caplan's stroke: a clinical approach. $4^{\text {th }}$ ed. Philadelphia: Elsevier/Saunders; 2009. p. 22.

51. Lin CJ, Yang JT, Huang YC, Tsai YH, Lee MH, Lee M, et al. Favorable outcome of blood urea nitrogen/creatinine-based hydration therapy $3 \mathrm{mo}$ after acute ischemic stroke. Am J Emerg Med 2016;34:2414-8. 